\title{
A Review on the Use of Bamboo for Earthwork Construction
}

\author{
Mokhammad Farid Ma'ruf ${ }^{1, *}$ \\ ${ }^{1}$ Civil Engineering Department, Jember University, Jl. Kalimantan 37 Kampus Tegalboto 68121 \\ Jember Indonesia
}

\begin{abstract}
Bamboo becomes a promising engineering material widely utilized for constructions. It is likely a composite material with fibred reinforcement in one direction to make its good flexural strength. Bamboo has been traditionally made use for structural components. Recently, the applications of bamboo for earthwork constructions are reported both experimental and real project. Pile foundations for houses, bamboo pile and nail for slope stability, foundation grid for embankment, and bamboo pile-mattress for railway and reclamation project are among others of the application. This paper discusses the use of bamboo for earthwork construction. Particular discussion is addressed to bamboo pile-mattress that successfully installed for various project in Indonesia. The appropriate field characteristic for bamboo application is specified. The design step and theoretical based are discussed as well.
\end{abstract}

\section{Introduction}

Bamboo has a long history to be used as construction material all over the world, especially in tropical and semi tropical countries. It is characterized by its strength and low weight. Bamboo is also easy worked even with very simple tools. Bamboo can be formed to almost all part of traditional house [1], footbridge over small stream, and river bank stabilization (Fig. 1).

Of the author knowledge, research and implementation of bamboo for structural element reinforcement has been reported about five decades ago [2,3]. Since then many works to do intensively to improve the application of bamboo in structural element [4-11] focusing on bamboo concrete reinforcement and its durability both with and without treatment. The use of bamboo for earthwork construction has a long tradition also as well as for structural construction. Fang and his colleagues reported their work on soil reinforcement for slope stability on highway project [12-14]. However, scarce publications of bamboo application on earthwork construction have been recorded afterward. In the last two decades, the earthwork construction using bamboo has increased significantly. Various applications have been reported either in laboratory scale or field implementations. Bitumen-bamboo mesh composite [15], sheet pile and soil nailing [16, 17], bamboo cell [18, 19], bamboo

* Corresponding author: farid.teknik@unej.ac.id 
grid or network [20 - 23], bamboo chips [24,25], bamboo pile [26, 27, 28], bamboo mattress [29,30], bamboo piled - mattress [31,32] are among others.

This paper intends to discuss the use of bamboo on earthwork construction. Various applications both laboratory and field scale are elaborated as well but limited on bamboo as earthwork structural element only. The design step and theoretical based are discussed as well.

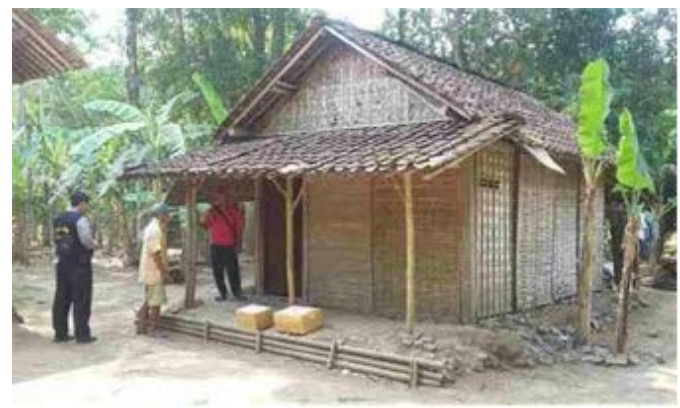

a

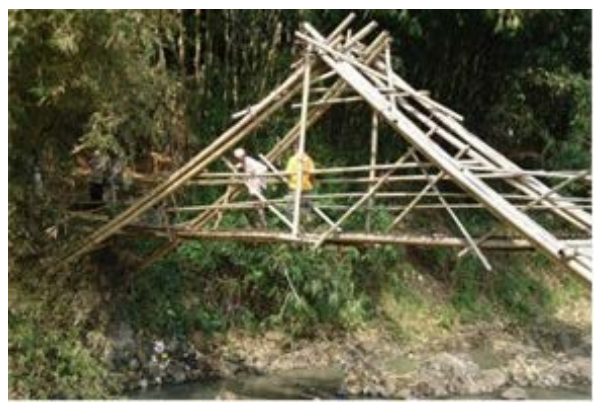

b

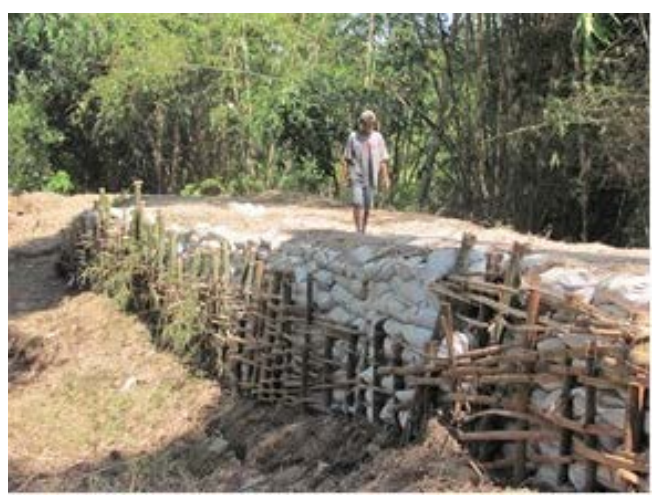

C

Fig. 1. Traditional use of bamboo in Indonesia.

\section{Mechanical properties of bamboo}

Bamboo becomes a promising construction material because of its mechanical properties are comparable with other construction material. The properties strongly depend on bamboo species, growing conditions, and culm position [33]. Bamboo has density about $700-800 \mathrm{~kg} / \mathrm{m}^{3}$ in which the fibbers contribute about $60-70 \%$ of total weight.

Bamboo has very strong tension compare to woods but low to medium modulus of elasticity about $35-70 \mathrm{kN} / \mathrm{mm} 2$ depends on bamboo diameter and wall thickness of the culm [34]. The high tension is in fibbers direction but more critical in perpendicular one. Since only lignin matrix takes place for bamboo endurance during loading in transverse direction. [35] suggested treating bamboo as structural element instead of material, therefore bending stiffness (EI) is more appropriate than modulus of elasticity. The moment of inertia (I) was calculated as follows:

$$
I=\frac{\pi}{64}\left[D^{4}-(D-2 t)^{4}\right]
$$


$\mathrm{D}$ and $\mathrm{t}$ are the average external diameter and the average wall thickness of the culm respectively.

\section{Earthwork Application of Bamboo}

\subsection{Bamboo Cell}

The use of bamboo for bamboo cell was reported by Hedge and Sitharam [18,19]. The work was on laboratory scale. Fresh bamboo culm was sliced to obtain a thin strip with $25 \mathrm{~mm}$ width. The strips were then woven together to form a grid. The grids were fixed together using wire to form a shape which similar in shape and size with commercial geocell. The bamboo cell and bamboo grid were utilized either individually or in combination.

Performance of the reinforcement is represented by ratio between footing settlement $(S)$ and footing width $(B)$ (Fig. 2). The bearing capacity of soil reinforced with bamboo cell and grid increased about $1.2-1.5$ times than one that reinforced by geocell and geogrid. This high performance may be due to higher tensile strength and surface roughness of bamboo element compare to geosynthetic ones. Bamboo had tensile strength and surface roughness about nine times and 3.5 times respectively compare to that of geosynthetic [19]. However, one should criticize that bamboo strip that being tested for tensile strength was much thicker than one for bamboo cell and bamboo grid.

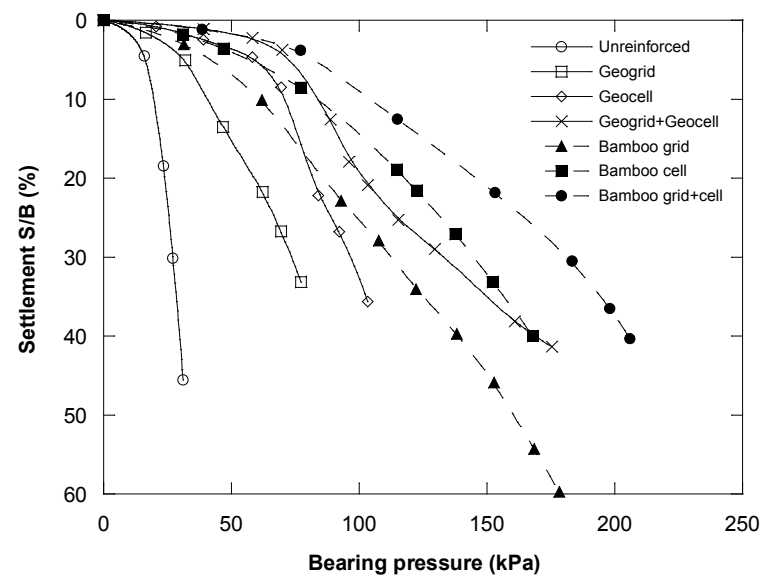

Fig. 2. Bearing pressure - settlement curves for various reinforcement (adapted from [19])

\subsection{Bamboo Pile}

Bamboo pile can be used as stabilization and reinforcement system instead of being used for direct support of building. [28] suggested to install bamboo pile behind sheet pile wall to reduce active earth pressure or at excavation base in front of sheet pile to increase passive earth pressure. Though the mechanism was unclear, if such assumption is true, then the stability of excavation slope will increase due to the change of the working pressure. 


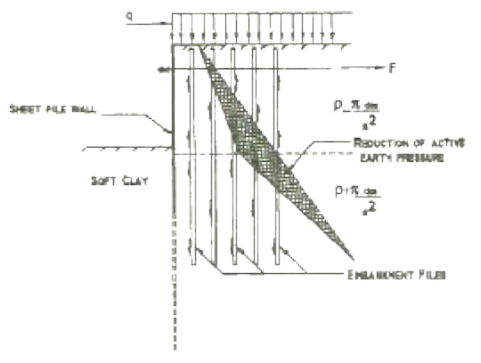

REDUCTION OF ACTIVE EARTH PRESSLRE

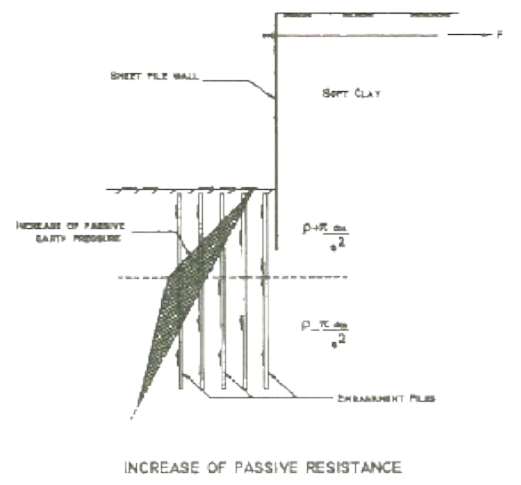

Fig. 3. Stabilization of excavation using bamboo pile (adapted from [27]).

$[26,36]$ had investigated the behaviour of bamboo pile to support shallow footing in the laboratory scale. Instead of placing the bamboo below the footing, they install the bamboo piles around the footing (Fig. 4). [36] reported that the bearing capacity increased with the pile extend (R) and pile length (L) but decreased with pile spacing (S). However, the bearing capacity converged when the spacing equal to footing width. [36] conducted experiments with only a row of bamboo pile to fence off the footing but with various distance from it. The bearing capacity improved when the bamboo piles closer to the footing. However, it decreased if the pile row was beneath the footing.

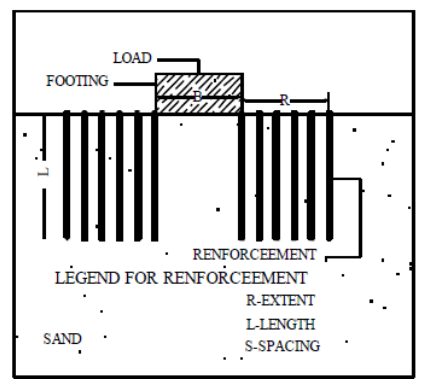

Fig. 4. Bamboo pile plan for footing reinforcement (adapted from [36]).

\subsection{Bamboo Soil Nail and Sheet Wall}

Bamboo grid that served as sheet wall has a long tradition in remote area of Indonesia (Fig. 1c). However there is no scientific investigation reported. Recent works of Dai and his colleagues [16, 17] combined bamboo soil nails and bamboo pile wall. The bamboo construction was applied to stabilize a $5 \mathrm{~m}$ excavation slope on loose silt resting on a deep layer of sludge (Fig. 5). The system consisted of bamboo grid reinforced shotcrete to cover the excavation slope; bamboo soil nails to support the shotcrete; and bamboo piles in a row to serve as sheet wall. Two rows of bamboo piles were installed with $40 \mathrm{~cm}$ space in between. The piles were put in through soil boring every $20 \mathrm{~cm}$. Four series of bamboo soil nails were applied and connected to the bamboo grids. The detail installation and calculation method can be found in [16]. 


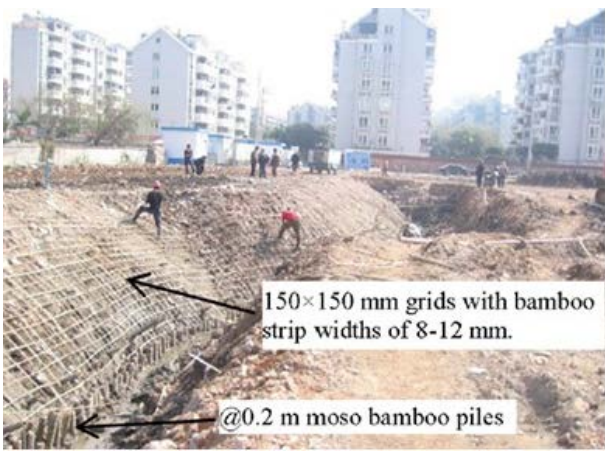

a

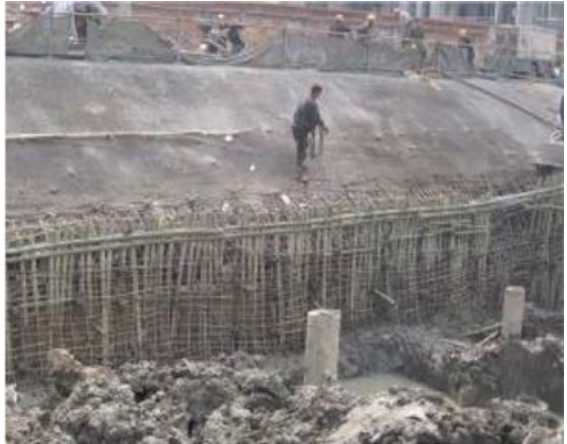

b

Fig. 5. Combination of bamboo soil nails, bamboo sheet piles, and bamboo reinforced shotcrete for slope stabilization (adapted from [16, 17]).

[16] reported the numerical analysis of bamboo reinforcement system and its monitoring results. The bamboo reinforcement system provided better reinforcement than ones from steel pipe. The bamboo soil nails produced almost 2.8 times of capacity than that of pipe nails. The new bamboo wall brought better stability performance than that of conventional steel pipe both numerically and in real project. The inclusion of bamboo branch during soil nailing had contributed higher soil-structure friction to provide large both soil nail and sheet wall capacity. However, in contrast to conventional soil nailing wall, bamboo soil nails should increase the length of the nail with increasing its depth.

\subsection{Bamboo Grids and Mattress}

Marto and her colleagues examined the performance of bamboo-geotextile composite (BGC) and high strength geotextile (HSG) for soft clay embankment reinforcement [29, 30]. The bamboo grid was laid down under the geotextile to provide a platform for laying and sewing it and forming a BGC. The reports were rather contradictive since both papers had showed different results. One reported BGC conceded lesser vertical and lateral deformation but another provided the opposite one.

[37] evaluated the bamboo grids and bamboo pile-mattress application for soft soil reinforcement. 4 layers of bamboo grids (Fig. 6) were extended over deep layer of soft soil to support $6.2 \mathrm{~m}$ embankment. The grids pattern had a space of $1 \mathrm{~m} \mathrm{x} 1 \mathrm{~m}$ and regarded as embankment foundation to increase subgrade stiffness. The numerical analysis provided safety factor of 1.9 for embankment slope stability. The analysis as well as analytical one predicted similar induced consolidation settlement. The prediction was comparable with ongoing field monitoring. The reinforcement succeeded to increase the bearing capacity but not to reduce the consolidation settlement.

Bamboo piled-mattress evaluated in [37] was also discussed in detail in [31, 32]. The bamboo mattress was bamboo culm that being set up in parallel with very minimum space in between. The bamboos were tied up with either natural or fibre wire. In case more than a mattress required, the mattresses were set up in zigzag with the adjacent ones. The bamboo pile contained $3-5$ bamboo culms that were bundled with wire. The top of the pile was fixed to the mattress to form the piled-mattress system. The system served various functions when installed for soft soil reinforcement. The mattress distributed the working load to the soil, change the critical failure surface location, and provide uplift buoyance force. The pile works as friction on to support the mattress. 


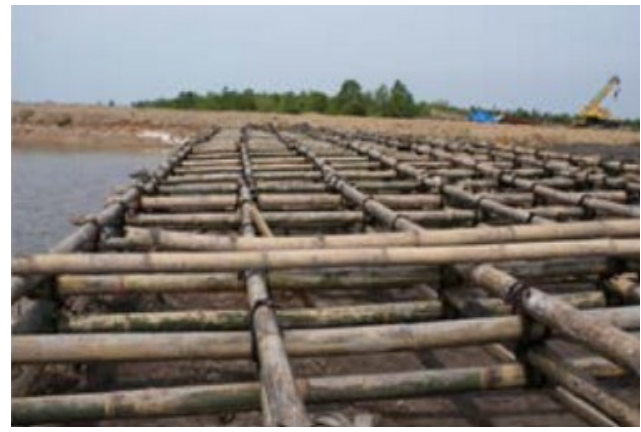

Fig. 6. Bamboo grid for soft soil reinforcement (adapted from [37]).

For design calculation, $E I_{m}$ of the mattress is easily calculated by multiplying elasticity modulus of bamboo with mattress moment of inertia of the mattress $I_{m}$. The inertia is following the equation:

$$
I_{m}=\sum I+\sum A d^{2}
$$

$I$ is bamboo moment of inertia and can be calculated using (1). $A$ is cross area of bamboo. $d$ is the distance between bamboo element and the reference point of the mattress. In plane strain modelling, the bamboo pile should be treated as node to node anchor instead of pile beam in which the pile stiffness is replaced by bamboo pile bearing capacity.

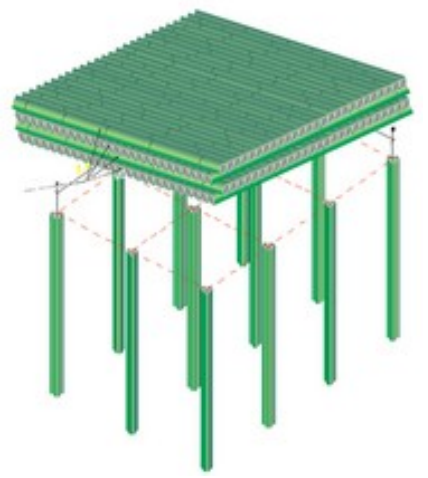

Fig. 7. Bamboo piled-mattress system (adapted from Prof. Masyhur Irsyam presentation)

Following the described procedure, $[31,32,37]$ showed that the soil bearing capacity increased significantly to support the embankment. The embankment factor of safety also improved as well. However, the settlement occurred similar to one without reinforcement.

\section{Discussions}

The most problem of the bamboo is its durability. Without treatment, bamboo durability is less than 2 years. Preservation can make the durability last $4-7$ years. Soaking bamboo in the flowing water is able to increase the durability. According to Indonesian local belief, it may last more than 10 years. This belief was also reported in other country [38]. The durability restricts bamboo to suit only for temporary structures. Bamboo will serve longer time in case it always in submerged condition. Using bamboo for earth retaining structure 
can be considered if it is temporary structure $[16,17]$. For permanent one, the maintaining schedule and methods should be prepared in advanced to provide sustainable level of services.

Bamboo reinforcement for embankment support can be applied both for temporary or permanent one. The most problem of embankment is excessive strain during embankment process. The soil strength increases with time when consolidation takes place. When the bamboo serviceability reduces, the soil mobilized soil strength alters it.

Bamboo serves its full strength when the culm is in its original condition. Slicing and cutting will reduce bamboo strength significantly. Using bamboo grid or mattress will provide better strength than that of bamboo strips.

\section{Conclusions}

A review on earthwork construction using bamboo was conducted. Bamboo can be utilized for various earthwork constructions, such as sheet pile, soil nailing, shotcrete reinforcement, grids, mattress and pile. Bamboo reinforcement will increase soil strength to provide adequate stability and bearing capacity. However it cannot reduce settlement. Since durability is a major concern, the use of bamboo for permanent earth structure requires more factors to be considered.

\section{References}

1. D. L. Jayanetti, P. R. Follet, Bamboo in construction (Trada, UK, 1998)

2. F.E. Brink, P. J. Rush, Bamboo reinforced concrete construction (US Naval Civil Engineering Laboratory, California, USA, 1966)

3. K. L. Saucier, E. F. Smith, Design, Analysis, and Construction of Precast Concrete Elements with Bamboo Reinforcement (Part 926 of Miscellaneous paper, Waterways Experiment Station U.S, 1967)

4. D. J. Cook, R. P. Pama, R. V. Singh, Mag. Concr. Res. 30(104), 145 (1978)

5. K. Ghavami, Cem. Concr. Compos. 27, 637 (2005)

6. H. C. Lima, F. L. Willrich, N. P. Barbosa, M. A. Rosa, B. S. Cunha, Mater. Struct. 41, 981 (2008)

7. A. Kaware, U. R. Awari, M. R. Wakchaure, IJIRSET 2(6), 2450 (2013)

8. P. Sharma, K. Dhanwantri, S. Mehta, IJCER 5(3), 249 (2014)

9. A. Agarwala, B. Nandab, D. Maitya, Const. Build. Mat. 71, 610 (2014)

10. S. Y. Kute, M. R. Wakchaure, J. Inst. Eng. India Ser. A 94(4), 235 (2014)

11. A. Javadian, M. Wielopolski, I. F. C. Smith, D. E. Hebel, Consts. Build. Mater. 122, 110 (2016)

12. H. Y. Fang, H. J. Mehta, Proc. 6th WCEE New Delhi, India, 3, 25 (1977)

13. H. Y. Fang, Proc. Symp. Soil Reinf. \& Stab. Tech. Eng. Prac. Sydney, 191 (1978)

14. H. Y. Fang, T. R. Moore, M. F. Rovi, Proc. 3th CREAAA, Taipei, Taiwan, 413 (1981)

15. D. S. V. Prasad, M. A. Kumar, G. V. R. P. Raju, Global J. Res. Eng. 10(1), 2 (2010)

16. Z. H. Dai, W. D. Guo, G. X. Zheng, Y. Ou, Y. J. Chen, Int. J. Geomech. 16(5), 04016012-1 (2016)

17. Z. H. Dai, Y. J. Chen, G. X. Zheng, W. D. Guo, GeoShanghai 2014, 720 (2014) 
18. A. Hegde, T. G. Sitharam, J. Mater. Civ. Eng. 27(9), 04014256-1(2015)

19. A. Hegde, T. G. Sitharam, Int. J. of Geosyn. and Ground Eng. 1(2), 13 (2015)

20. E. Susila, F. Agrensa, J. Eng. Tech. Sci. 47(2), 207 (2015)

21. A. Waruwu, J. of Civ. Eng. Res. 4(3A), 96 (2014)

22. M. Yuan, J. H. Ding, Y. L. Cao, World J. of Eng. Tech. 2, 68 (2014)

23. C. T. Toh, S. K. Chee, C. H. Lee, S. H. Wee, Geotext Geomembranes 13, 357 (1994)

24. H. Shigematsu, Y. Sakiura, Y. Tanida, Proc. Of CECAR7, - (2016)

25. S. Ismanti, N. Yasufuku, Jap. Geot. Soc. Special Pub. 5(2) 161 (2017)

26. P. P. Rahardjo, in Ground Improvement Case Histories, 899 (Elsevier, 2005)

27. J. N. Mandal, V. R. Manjunath, Const. Build. Mat. 9(1), 35(1995)

28. B.B. Broms, I.H. Wong, Proc. of Third International Geotechnical Seminar on Soil Improvement Methods, Singapore, (1985)

29. A. Marto, B. A. Othman, F.Kasim, I. Bakar, AMM 587, 77 (2012)

30. A. Marto, B. A. Othman, Proc. of IPCBEE 8, 129 (2011)

31. M. Irsyam, S. Krisnanto, S. P. M. Wardhani, Proc. of the 2nd Int. Conf. GEDMAR08, Nanjing, China, 165 (2008)

32. M. Irsyam, S. Krisnanto, Civ. Eng. Forum 18, 667 (2008) in Indonesian

33. J. J. A. Janssen, Designing and Building with Bamboo: INBAR Technical Report 20. (International Network for Bamboo and Rattan, Beijing, China, 2000)

34. J. J. A. Janssen, Mechanical Properties of Bamboo (Springer Science+Business Media Dordrecht, Netherland, 1991)

35. D. Trujillo, S. Jangra, J.M. Gibson, Proc. of ICE - Struc. And Build. 170:4, 284 (2017)

36. J.N.Jha, A.K Choudhary, K.S Gill, Int. J. of Plasma Sci. \& Eng. 03(01),167 (2010)

37. E. Susila, F. Agrensa, J. Eng. Technol. Sci.47(2), 207, (2015)

38. N. Adhikary, Proc. of 1st Int. Conf. On Modern Bamboo Structures, Changsa, China, 103 (2007) 